\title{
Austenite reversion in low-carbon martensitic stainless steels - a CALPHAD-assisted review
}

Niessen, Frank

Published in:

Materials Science and Technology

Link to article, DOI:

10.1080/02670836.2018.1449179

Publication date:

2018

Document Version

Peer reviewed version

Link back to DTU Orbit

Citation (APA):

Niessen, F. (2018). Austenite reversion in low-carbon martensitic stainless steels - a CALPHAD-assisted review. Materials Science and Technology, 34(12), 1401-1414 . https://doi.org/10.1080/02670836.2018.1449179

\section{General rights}

Copyright and moral rights for the publications made accessible in the public portal are retained by the authors and/or other copyright owners and it is a condition of accessing publications that users recognise and abide by the legal requirements associated with these rights.

- Users may download and print one copy of any publication from the public portal for the purpose of private study or research.

- You may not further distribute the material or use it for any profit-making activity or commercial gain

- You may freely distribute the URL identifying the publication in the public portal

If you believe that this document breaches copyright please contact us providing details, and we will remove access to the work immediately and investigate your claim. 


\title{
Austenite reversion in low-carbon martensitic stainless steels - a CALPHAD-assisted review
}

\author{
Frank Niessen ${ }^{1,2}$ \\ ${ }^{1}$ The Danish Hydrocarbon Research and Technology Centre, Technical University of \\ Denmark (DTU), Kongens Lyngby, Denmark \\ ${ }^{2}$ Department of Mechanical Engineering, Technical University of Denmark (DTU), \\ Kongens Lyngby, Denmark \\ E-mail: contact@fniessen.com
}

\begin{abstract}
Low-carbon martensitic stainless steels with 11.5 - 16 wt.\% Cr, $4-8$ wt.\% Ni and low interstitial content, $\mathrm{C}<0.07 \mathrm{wt} . \%$ and $\mathrm{N}<0.06 \mathrm{wt} . \%$ are characterised by their outstanding property combination of high corrosion resistance, strength, ductility and impact toughness, obtained by formation and stabilisation of finegrained reverted austenite from lath martensite upon annealing in the inter-critical region. This review reflects on the mechanisms that govern the formation and stabilisation of reverted austenite and the early stage of austenite reversion close to $A_{1}$ with focus on the role of residual stresses in martensite. The review is assisted by the computation of phase equilibria. Literature data on $\mathrm{Cr}$ and $\mathrm{Ni}$ concentrations of the reverted austenite/martensite dual-phase microstructure are assessed with respect to predicted concentrations obtained from phase equilibria. Reasonable agreement was found for concentrations in martensite. Systematic excess of $\mathrm{Cr}$ in austenite of approx. 2 wt.\% relative to calculations was suspected to originate from the growth of $\mathrm{M}_{23} \mathrm{C}_{6}$ with a coherent interface to austenite. Within large scatter, measured values of $\mathrm{Ni}$ in austenite were on average $2 \mathrm{wt} . \%$ below predictions. Complex equilibration of the microstructure and experimental error are discussed as possible origins of the discrepancies.
\end{abstract}

Keywords: austenite reversion; microstructure evolution; solute partitioning; thermodynamics; CALPHAD; diffusion; martensite formation; residual stress; 


\section{Introduction}

Low-carbon martensitic stainless steels comprise the group of supermartensitic stainless steels, soft martensitic stainless steels and precipitation-hardening versions. While the individual alloy groups are optimised towards different application fields such as weldability, corrosion resistance or hardenability, all contain a nano-lamellar dual-phase microstructure of reverted austenite and tempered martensite through inter-critical annealing, i.e. annealing in the temperature region in which both ferrite and austenite are thermodynamically stable. The obtained 'reverted austenite' is distinguished from 'retained austenite', i.e. that is untransformed during cooling to room temperature [1]. Stabilisation of reverted austenite against martensite formation occurs primarily by the partitioning of austenite stabilising elements during diffusional reversion. The resulting fine-grained dual-phase microstructure lowers the yield strength, ultimate tensile strength and hardness, while ductility and impact toughness are significantly enhanced $[2-4]$.

The mechanisms leading to the reversion of austenite and the analysis of the stability of reverted austenite against martensite formation to thermal or mechanical treatments are the subject of numerous research articles published within the last decades. Newly emerging experimental and modelling methods enabled the progressive transition from a processing-property based approach to a microstructure-property based understanding of these materials. It therefore appears timely to review the present understanding of the reverse martensite-to-austenite phase transformation. As the title suggests, this review includes phase equilibrium calculations (so-called CALPHAD approach) to support the discussion.

The microstructure-property based characterization of the alloys in recent years has led to a wealth of quantitative literature data on the partitioning of $\mathrm{Ni}$ and $\mathrm{Cr}$ after partial reversion of austenite during inter-critical annealing of martensite. As reported data concerns different alloy systems and annealing parameters, and as discussion of the data is generally limited to the scope of the specific work, a collective representation of the data is established here to reveal underlying trends. As austenite reversion during isothermal annealing is accompanied by diffusion, it is of interest to verify whether the experimentally determined concentrations can be predicted by phase equilibria from thermodynamics modelling. Finally, the early stage of austenite reversion close to $A_{1}$ 
and the findings from the analysis of compositional data from literature are critically discussed.

\section{Scope}

The present review is limited to low-carbon martensitic stainless steels with $11.5-16$ wt.\% Cr, $4-8$ wt.\% $\mathrm{Ni}$ and low interstitial content, $\mathrm{C}<0.07$ wt.\% and $\mathrm{N}<0.06$ wt.\%, for which a fine-grained dual-phase structure of reverted austenite and tempered martensite forms by a diffusional mechanism during inter-critical annealing. In some steels austenite stability is sufficiently high for austenite reversion to occur by a displacive mechanism at temperatures where a diffusion controlled transformation is kinetically suppressed [5,6], which is not treated in this review. Austenite reversion and stabilisation by a diffusional mechanism is not limited to the alloys discussed here and can also be found in other alloy groups, as for example in medium manganese steels $[7,8]$. The mechanisms discussed in the present work can readily be transferred to other alloy systems, but that is beyond the scope of this review. The focus of this review lies on phase transformations rather than alloy properties. Only a short section is dedicated to the effect of reverted austenite on microstructure properties, including references for further reading.

\section{Current view on austenite reversion}

\section{Historical aspects and alloy design of low-carbon martensitic stainless steels}

These alloys are built on the Fe-Cr-Ni ternary system with additions of Mn, Mo, Si and particularly low contents of the interstitial elements C and N. In 1960, Irvine et al. [9] comprehensively described aspects of designing transformable $12 \% \mathrm{Cr}$ steels to obtain a strong and corrosion resistant material. A major challenge consisted of finding alloy compositions that could be solution treated without forming $\delta$-ferrite, maintained $A_{1}$ above $700{ }^{\circ} \mathrm{C}$ during $5 \mathrm{~h}$ isothermal tempering to avoid reaustinitisation during tempering, and kept $\mathrm{M}_{\mathrm{s}}$ above $200{ }^{\circ} \mathrm{C}$ to ensure complete transformation to martensite during cooling [9]. An Fe-0.1C-12Cr-2Ni-1.5Mo-0.3V (wt.\%) alloy was found most promising with respect to strength and impact toughness [9] (Table 1).

Additional stabilisation of austenite was necessary to maintain a transformable steel when increasing the $\mathrm{Cr}$ content for enhanced corrosion performance. As further 
addition of $\mathrm{C}$, one of the most effective austenite stabilising elements, would lead to $\mathrm{M}_{23} \mathrm{C}_{6}$ precipitation and thus deplete $\mathrm{Cr}$, other substitutional solutes needed to be considered instead [10]. Ni proved to be the most effective element, and substitution of $\mathrm{C}$ with $\mathrm{Ni}$ further led to a useful softening of virgin martensite, which manifests as increased impact toughness [10-12].

Following this paradigm, the Swedish steel manufacturers Bofors and Avesta reduced the $\mathrm{C}$ content to $0.06 \mathrm{wt} . \%$ to develop soft martensitic stainless steels with good corrosion resistance, high strength and high impact toughness for pressure vessel applications in the mid 60's of the last century [3,18-20] (Table 1). These steels

Table 1. Overview of typical alloy compositions and average mechanical properties of soft martensitic and supermartensitic stainless steels for specified annealing treatments with reference to conventional martensitic stainless steel; YS: Yield strength, UTS: Ultimate tensile strength, A: elongation until rupture, $\mathrm{K}_{\mathrm{V}}^{\mathrm{RT}}$ : Charpy-V impact toughness at room temperature

\begin{tabular}{|c|c|c|c|c|c|c|c|}
\hline $\begin{array}{l}\text { Alloy } \\
\text { designation }\end{array}$ & Reference & $\begin{array}{l}\text { Composition } \\
\text { [wt.\%] }\end{array}$ & $\begin{array}{l}\text { Annealing } \\
\text { treatment } \\
\mathrm{T}\left[{ }^{\circ} \mathrm{C}\right] / \mathrm{t}[\mathrm{h}]\end{array}$ & $\begin{array}{l}\mathrm{YS} \\
{[\mathrm{MPa}]}\end{array}$ & $\begin{array}{l}\text { UTS } \\
{[\mathrm{MPa}]}\end{array}$ & $\begin{array}{l}\mathrm{A} \\
{[\%]}\end{array}$ & $\begin{array}{l}\mathrm{K}_{\mathrm{V}}^{\mathrm{RT}} \\
{\left[\frac{\mathrm{J}}{\mathrm{cm}^{2}}\right]}\end{array}$ \\
\hline
\end{tabular}

Conventional martensitic stainless steel

\begin{tabular}{llllllll}
\hline generic & $\begin{array}{l}\text { Irvine et al., } \\
1960[9]\end{array}$ & $\begin{array}{l}\text { Fe-0.1C-12Cr-2Ni- } \\
1.5 \mathrm{Mo}-0.3 \mathrm{~V}\end{array}$ & $650 / 1$ & 670 & 860 & 19 & $\geq 68$ \\
\hline
\end{tabular}

Soft martensitic stainless steels

\begin{tabular}{|c|c|c|c|c|c|c|c|}
\hline $\begin{array}{l}\text { Bofors } \\
2 \mathrm{RMO}\end{array}$ & $\begin{array}{l}\text { Grounes and } \\
\text { Rao, } 1969 \\
{[3]}\end{array}$ & $\begin{array}{l}\mathrm{Fe}-0.06 \mathrm{C}-13 \mathrm{Cr}- \\
6 \mathrm{Ni}-1.5 \mathrm{Mo}-0.6 \mathrm{Mn}- \\
0.4 \mathrm{Si}\end{array}$ & 590 & $\geq 620$ & $\geq 830$ & $\geq 15$ & 105 \\
\hline $\begin{array}{l}\text { Avesta } \\
248 \mathrm{SV}\end{array}$ & $\begin{array}{l}\text { Grounes and } \\
\text { Rao, } 1969 \\
{[3]}\end{array}$ & $\begin{array}{l}\text { Fe-0.035C-16Cr- } \\
5 \mathrm{Ni}-1 \mathrm{Mo}-0.8 \mathrm{Mn}- \\
0.5 \mathrm{Si}\end{array}$ & 580 & $\geq 620$ & $\geq 830$ & $\geq 15$ & 132 \\
\hline $\begin{array}{l}\text { EN } 1.4405 \\
\text { (cast alloy) }\end{array}$ & $\begin{array}{l}\text { Niederau, } \\
1982[2]\end{array}$ & $\begin{array}{l}\mathrm{Fe}-<0.07 \mathrm{C}-16 \mathrm{Cr}- \\
5 \mathrm{Ni}-1.5 \mathrm{Mo}-<1 \mathrm{Mn}- \\
<1 \mathrm{Si}\end{array}$ & 580 & 650 & 900 & $\geq 17$ & 105 \\
\hline EN 1.4418 & $\begin{array}{l}\text { Dawood et } \\
\text { al., } 2004 \\
{[13,14]}\end{array}$ & $\begin{array}{l}\mathrm{Fe}-0.05 \mathrm{C}-15.5 \mathrm{Cr}- \\
5.6 \mathrm{Ni}-0.76 \mathrm{Mo}- \\
0.4 \mathrm{Mn}-0.4 \mathrm{Si}\end{array}$ & 625 / 4 & 690 & 880 & 10 & 260 \\
\hline
\end{tabular}

Supermartensitic stainless steels

\begin{tabular}{|c|c|c|c|c|c|c|c|}
\hline $\begin{array}{l}13 \mathrm{CrS} \\
\text { (UNS } \\
\text { S41525) }\end{array}$ & $\begin{array}{l}\text { Kondo et al., } \\
1999[10,15]\end{array}$ & $\begin{array}{l}\mathrm{Fe}-0.01 \mathrm{C}-12 \mathrm{Cr}- \\
6 \mathrm{Ni}-2.5 \mathrm{Mo}-\mathrm{Ti}\end{array}$ & $\begin{array}{l}850 / 0.5+ \\
630 / 1\end{array}$ & $\geq 550$ & $\geq 750$ & / & 290 \\
\hline $\begin{array}{l}\text { Vítkovice, } \\
\text { generic }\end{array}$ & $\begin{array}{l}\text { Tvrdy et al., } \\
2002[16]\end{array}$ & $\begin{array}{l}\text { Fe-0.017C-13Cr- } \\
6.2 \mathrm{Ni}-2.4 \mathrm{Mo}- \\
0.6 \mathrm{Mn}-0.3 \mathrm{Si}\end{array}$ & $600 / 6$ & 540 & 870 & 19 & 185 \\
\hline $\begin{array}{l}\text { Industeel, } \\
\text { generic }\end{array}$ & $\begin{array}{l}\text { Toussaint } \\
\text { and Dufrane, } \\
2002[17]\end{array}$ & $\begin{array}{l}\mathrm{Fe}-0.008 \mathrm{C}-11.8 \mathrm{Cr}- \\
4.8 \mathrm{Ni}-1.5 \mathrm{Mo}- \\
1.9 \mathrm{Mn}-0.2 \mathrm{Si}-0.5 \mathrm{Cu}\end{array}$ & 625 & $\begin{array}{l}600 \\
650\end{array}$ & $\begin{array}{r}880 \\
900\end{array}$ & -25 & 195 \\
\hline
\end{tabular}


contained small amounts of retained austenite and formed reverted austenite upon intercritical annealing. Precipitation-hardening steels are designed with a similar base alloy composition, but solutes such as $\mathrm{Cu}$, $\mathrm{Mo}$ and $\mathrm{Nb}$ enable precipitation hardening $[4,21,22]$.

Further advances in steelmaking enabled the development of modern supermartensitic stainless steels in the 90's of the last century, which generally consist of $10.5-13.5$ wt.\% of $\mathrm{Cr}$ to enable passivation, very low $\mathrm{C}$ content (preferably $<0.01$ wt.\%) to enhance weldability and impact toughness, around $4-6 \mathrm{wt} \% \mathrm{Ni}$ to enable martensite formation, and increased Mo content $(0.5-2.5$ wt. $\%)$ to enhance resistance to localised corrosion and sulphide stress cracking [10-12,23-25] (c.f. overview in Table 1).

\section{Solution treatment, martensite formation and tempering of martensite}

Before austenite reversion from martensite is obtained by inter-critical annealing, lowcarbon martensitic stainless steels are solution treated in the austenite single-phase region to obtain homogeneous austenite as a parent phase for lath martensite. Some alloys contain micro- alloying elements, such as $\mathrm{Ti}, \mathrm{Nb}$ or $\mathrm{V}$, to form carbides and nitrides that pin the austenite grain boundaries during solution treatment to limit grain growth $[23,26]$. Austenite transforms to martensite during cooling over a narrow transformation range, with martensite formation starting at a relatively low temperature $\left(M_{s} \approx 260-130{ }^{\circ} \mathrm{C}\right)$ and finishing just above [27-32], or in exceptional cases even below [2,33], room temperature. Martensite forms with less than $\sim 2^{\circ}$ deviation [34] from a Kurdjumow-Sachs orientation relationship with austenite, $(111)_{\gamma}\left\|(011)_{\alpha^{\prime}},[10 \overline{1}]_{\gamma}\right\|[1 \overline{1} 1]_{\alpha \prime}$ [35]. Even though the exact nature of the interface associated with the orientation relationship is still subject of current research $[36,37]$, it has to be semi-coherent, consisting of periodic steps with coherent patches [38,39]. The low-carbon martensitic stainless steels have a high hardenability and are insensitive to the applied quenching rate $[4,11,17]$. Recent work showed that, as a consequence of the low $M_{S}$ temperature and interstitial content, no interstitial segregation by auto-tempering or 6 months of room temperature aging was observed [40]. In contrast, clustering of carbon at room temperature was reported in Ref. [41], without specifying the aging time. Martensitic transformation leads to transformation strains, which may be partially accommodated by retained austenite. During the 
transformation, martensite initially experiences high tensile stress, which then gradually decreases towards the end of the transformation (down to $\sim 40 \mathrm{MPa}$ ), while retained austenite experiences significant compressive stress towards the end of the transformation (up to $\sim-900 \mathrm{MPa}$ ) [42].

Lath martensite shows very high dislocation densities, similar to heavily coldworked alloys [43]. Quantitative studies on dislocation densities revealed $\sim 4 \times 10^{15} \mathrm{~m}^{-2}$ in an Fe-0.03C-15.5Cr-5Ni (wt.\%) precipitation hardening steel [44] and $\sim 7 \times 10^{14} \mathrm{~m}^{-2}$ in an Fe-0.04C-15.5Cr-5Ni (wt.\%) soft martensitic stainless steel [45] in as-quenched conditions.

When the dislocation-rich microstructure is reheated to the inter-critical region, $\mathrm{C}$ and $\mathrm{N}$ partition from solid solution and diffuse to lattice defects in order to minimize local strain fields [27]. Because of the low interstitial content, no transition carbides are formed during the tempering of martensite [21,46]. Tempering of Mo-containing steels at $400{ }^{\circ} \mathrm{C}$ [21] and $\mathrm{Cu}$-containing steels at 450 to $480{ }^{\circ} \mathrm{C}[29,47-50]$ leads to secondary hardening by precipitation of $\mathrm{Mo}_{2} \mathrm{C}$ and $\mathrm{Cu}$ precipitates, respectively. Generally, the kinetics and magnitude of secondary hardening in specific alloys is sensitive to the amount of available interstitial elements and the content of precipitate forming substitutional alloying elements. During further heating, concurrent recovery of the martensite matrix and austenite reversion at grain boundaries commence at approx. 500 to $550{ }^{\circ} \mathrm{C}[45,51]$, leading to a reduction in dislocation density by approx. an order of magnitude [45].

\section{Nucleation and growth close to $A_{1}$}

$\mathrm{A}_{1}$, i.e. the ferrite-to-austenite $(\alpha$-to- $\gamma)$ phase transition temperature in thermodynamic equilibrium, may conventionally be obtained from thermodynamics modelling. In the present system, the prediction of extensive partitioning of solute in austenite and ferrite at low temperature leads to a small fraction of stable austenite in thermodynamic equilibrium. In reality, an alloy undergoes martensite formation during cooling, such that austenite forms from an approximately homogeneous distribution of solute during reheating, rendering the prediction of $A_{1}$ from thermodynamic equilibrium unfeasible. $\mathrm{A}_{\mathrm{c} 1}$, the experimentally determined $\alpha$-to- $\gamma$ transition temperature during heating, is on the other hand strongly dependent on the heating rate $[9,27,52,53]$ and thus not an explicit quantity. In the present case the phase transition temperatures $A_{1}$ 
and $A_{3}$ therefore refer to the phase transition temperatures obtained during very slow

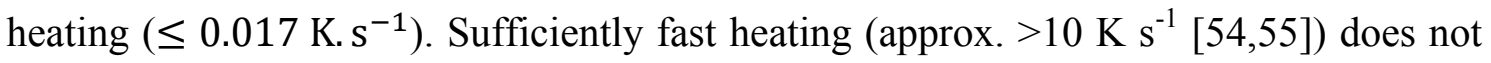
allow enough time for long-range diffusion and thus leads to transformation by a displacive mechanism instead.

Close to $\mathrm{A}_{1}$ (composition dependent at $\sim 500-550^{\circ} \mathrm{C}$ ) allotriomorphic reverted austenite with film morphology forms at lath boundaries [55-60] with little or no deviation from the Kurdjumow-Sachs orientation relationship [35,61,62]. All reported micrographs of annealed microstructures in the temperature range 500 to $575{ }^{\circ} \mathrm{C}$ (c.f. reference list in Table 2) reveal that austenite grows from the lath boundary into only one of the laths (Figure 1a) $[1,55,60,63]$. Above this temperature, austenite films begin to grow into both laths adjacent to a lath boundary (Figure 1b) $[55,58,60]$. In the case of pre-existing inter-lath retained austenite, immediate growth from retained austenite occurs, as no nucleation is required [59]. For the film morphology, austenite memory, i.e. the tendency of reverted austenite to form in the orientation of the prior austenite grain, is commonly observed $[27,59,64]$. Further, reverted austenite has been reported to form cooperatively with $\mathrm{M}_{23} \mathrm{C}_{6}$ carbides with a cube-cube orientation relationship, $\{100\}_{\gamma}\left\|\{100\}_{\mathrm{M}_{23} \mathrm{C}_{6}},\langle 001\rangle_{\gamma}\right\|\langle 001\rangle_{\mathrm{M}_{23} \mathrm{C}_{6}} \quad[33,41,58,60,65] . \quad$ According to thermodynamic equilibrium, growth of austenite requires an inward-flux of $\mathrm{Ni}$ and outward-flux of $\mathrm{Cr}$ [27] (Figure 2), while growth of $\mathrm{M}_{23} \mathrm{C}_{6}$ requires the opposite fluxes. Cooperative growth should thus be facilitated by a gradient in chemical potential and a resulting net flux of $\mathrm{Ni}$ and $\mathrm{Cr}$ across the interface. It was shown experimentally that $\mathrm{M}_{23} \mathrm{C}_{6}$ can bind sufficient carbon to leave austenite and martensite virtually carbon free $[41,66,67]$.

Figure 2 shows the equilibrium austenite fraction and $\mathrm{Cr}$ and $\mathrm{Ni}$ concentrations in austenite and ferrite as a function of temperature for a simple $\mathrm{Fe}-\mathrm{Cr}-\mathrm{Ni}$ system with average $\mathrm{Ni}$ and $\mathrm{Cr}$ concentrations of the analysed literature data in section 0 (c.f. Table 2). At low temperature, enhanced partitioning of $\mathrm{Ni}$ is required to form austenite which, together with slow substitutional diffusion kinetics, significantly limits the kinetics of austenite reversion $[27,62,68]$. Nevertheless, the kinetics of austenite reversion at low temperature were measured to be significantly faster than predicted by modelling of bulk-diffusion, suggesting that grain boundary diffusion and diffusion along dislocations may be important mechanisms that significantly increase the transformation kinetics at these temperatures $[27,33,68]$. 
(d)

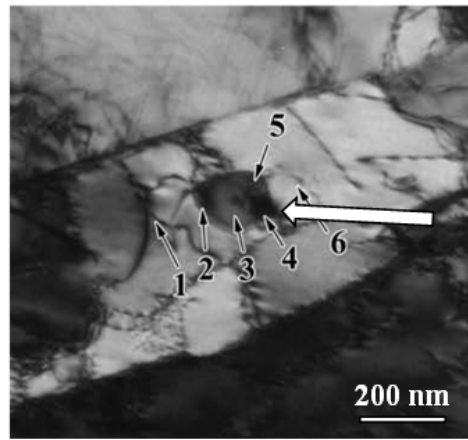

(c)

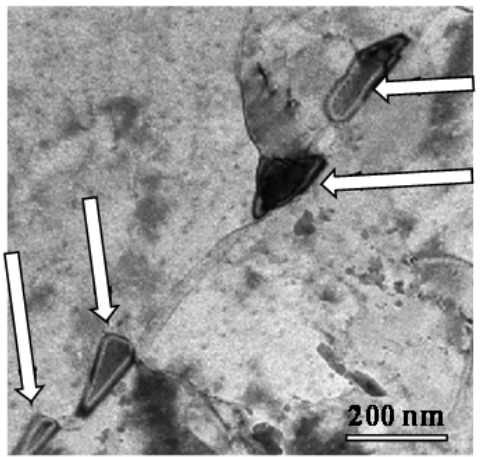

(b)

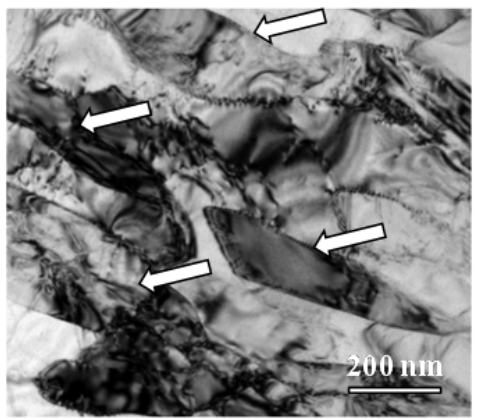

(a)

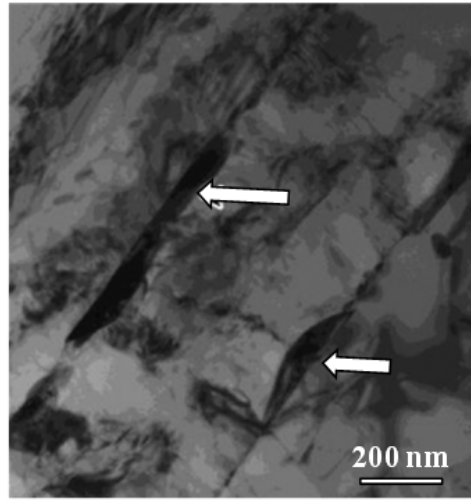

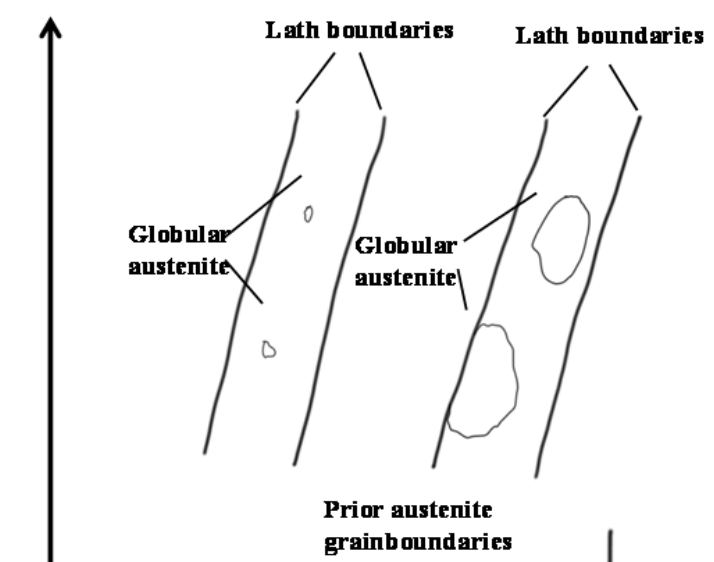
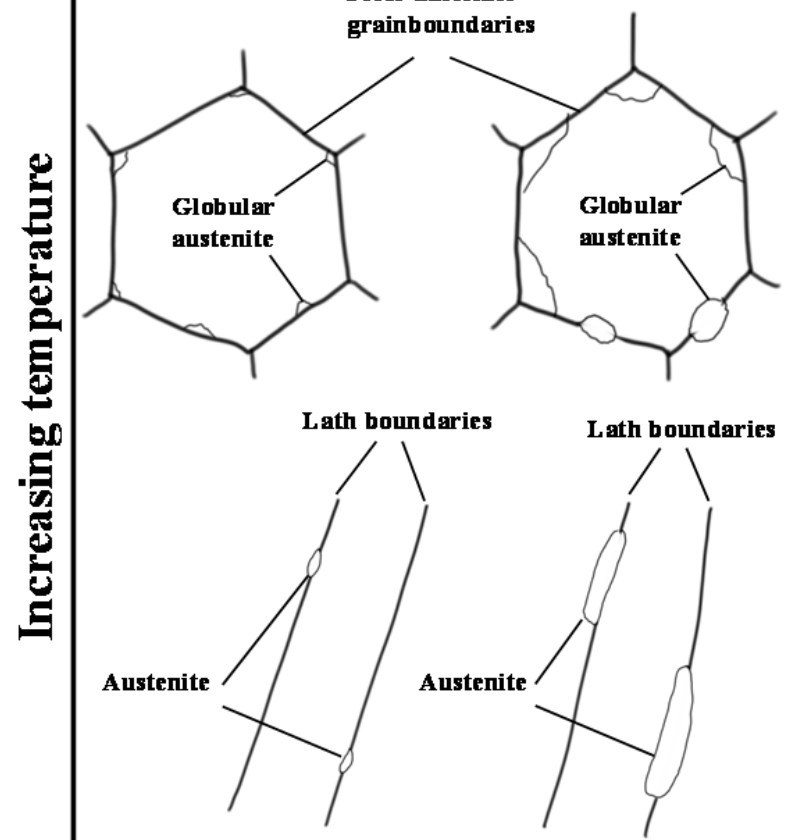

Lath boundaries

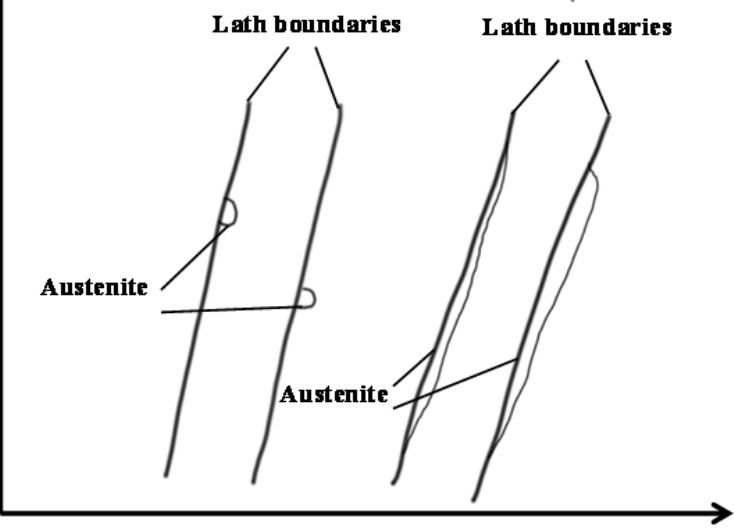

Increasing time

Figure 1. Bright-field micrographs and schematics of the evolution of the reverted austenite morphology with temperature and time in low-C martensitic stainless steels: (a) low temperature film morphology (Ref. [63]); (b) elevated temperature film morphology (Ref.[62]) ; (c) globular morphology at prior austenite grain boundaries (Ref. [1]); (d) globular morphology inside martensite laths (Ref. [58]); reverted austenite is marked with white arrows in the micrographs; Permissions for the use of figures from literature are automatically granted according to the STM signatory guidelines. 


\section{Nucleation and growth towards $A_{3}$}

At elevated temperature, typically $600-700{ }^{\circ} \mathrm{C}$, reverted austenite tends towards a globular morphology, first at prior austenite grain boundaries (Figure 1c) [56,57,59] and at higher temperature within martensite laths (Figure 1d) [55,60,70]. The reversion kinetics are significantly faster, mainly because of lower required partitioning of $\mathrm{Ni}$ (Figure 2), accelerated diffusion kinetics and increased prominence of bulk diffusion. Further, the increased driving force for austenite formation in this temperature range renders also incoherent interfaces [56] or the formation of new interfaces energetically favourable [55,60,70], manifested as more nucleation sites. It was found that in an Fe0.05C-12Cr-4Ni-0.5Mo (wt.\%) steel austenite reversion occurred without diffusion during isothermal annealing above $680^{\circ} \mathrm{C}$ [67]. Upon further heating grain growth and dissolution of $\mathrm{M}_{23} \mathrm{C}_{6}$ carbides continue towards a fully austenitic microstructure, which was reported to recrystallize spontaneously at $900{ }^{\circ} \mathrm{C}$ when heating with $0.17 \mathrm{~K}^{-1}{ }^{-1}, 70$ ${ }^{\circ} \mathrm{C}$ above $\mathrm{A}_{\mathrm{c} 3}$ [57].

\section{Stability of reverted austenite against martensite formation}

Reverted austenite that is formed close to $A_{1}$ is generally more stable against martensite formation upon cooling (or deformation) as compared to reverted austenite formed at higher temperature. There is a consensus that $\mathrm{Ni}$-enrichment in austenite decreases with

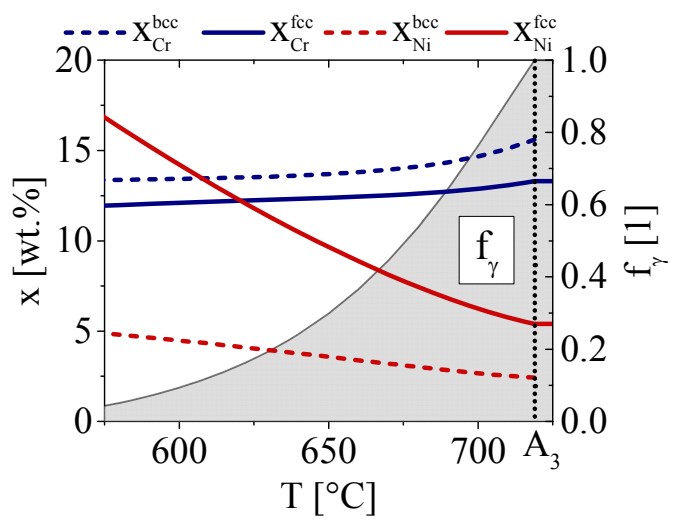

Figure 2. Ni and $\mathrm{Cr}$ concentration ( $x$ ) in austenite (fcc) and ferrite (bcc) as well as the molar fraction of austenite $\left(f_{\gamma}\right.$, grey area) from an equilibrium calculation of a representative Fe-13.3Cr-5.4Ni (wt.\%) ternary alloy. Partitioning of $\mathrm{Ni}$ increases with lower austenite fraction and temperature. (Allowed phases: liquid, fcc, bcc; software and thermodynamics database: Thermo-Calc 2017a TCFE6 [69]) 
increasing annealing temperature $[27,29,31,41,55,59,62,63,65-68,71-74]$, which is in qualitative agreement with the concentrations from thermodynamic equilibrium in Figure 2. The Ni concentration determines mainly the stability of reverted austenite against martensite formation, as more Ni reduces $M_{s}$. However, the compositional effect is considered insufficient to explain the stability of reverted austenite alone [41,72]. The increase in grain size $[63,65,75,76]$, the transition to a more globular grain morphology $[63,65]$ and softening of the surrounding martensitic matrix $[14,65]$ with increasing annealing temperature are anticipated to reduce the contribution of strain energy to the critical driving force for martensite nucleation [77], i.e. the stability of austenite. Findings by Zhang et al. [65] are particularly supportive of this mechanism, as intercritical annealing at $620^{\circ} \mathrm{C}$ was found to lead to higher fractions of reverted austenite with annealing time up to a maximum value, after which the fraction decreased again on further annealing. Even though the phase fraction of austenite approached equilibrium content, compositional equilibration (partitioning), carbide growth, recovery of martensite and spheroidisation of austenite continue $[65,66]$, which may affect the stability of reverted austenite.

Bilmes et al. [72] claimed that also a high dislocation density in reverted austenite could contribute to the stability of reverted austenite. This finding is doubtful, as the high dislocation density was identified by the dark appearance of austenite in a bright-field micrograph, which is generally indicative of an orientation contrast when using an objective aperture rather than the presence of dislocations [78]. Further, reverted austenite developed under continued diffusion is known to have low dislocation density [33,79], as opposed to reverted austenite formed by a displacive mechanism [6].

Reverted austenite either remains stable upon cooling, or transforms partially or completely to martensite $[30,45,62]$. Reverted austenite was reported to even have remained stable after sub-zero treatment at boiling $\mathrm{N}_{2}[2,72,74]$ and boiling $\mathrm{He}$ temperatures [41]. It is critically remarked that martensite formation in lath martensite, especially at sub-zero Celsius temperatures, is time-dependent, i.e. thermally activated, and kinetically suppressed at very low temperature. Transformation generally occurs in the temperature range $-150{ }^{\circ} \mathrm{C}$ to room temperature, which means that in the referenced cases $[2,41,72,74]$ martensite formation may be fully suppressed if cooling to, or heating from, boiling $\mathrm{N}_{2}$ temperature is performed sufficiently fast to suppress the 
thermally activated phenomena that control the rate of the austenite-to-martensite transformation in steel [80]. In a single case it was claimed that the fraction of austenite increases by applying sub-zero treatment [58], which is in obvious conflict with all above referenced observations.

Reverted austenite may also transform to martensite by strain-induced transformation and in this way enhances the plastic regime $[45,71,72,81]$. This mechanism known as transformation induced plasticity, has not been treated in depth in low-carbon martensitic stainless steels, but advanced in-situ experiments and modelling of strain-induced martensite formation have been performed in other variations of steels [82-88].

\section{Effect of reverted austenite on microstructure properties}

The effect of reverted austenite on the microstructure properties of low-carbon martensitic stainless steels is a broad topic and a proper treatment would exceed the scope of this review. A more detailed overview on the mechanical and corrosion properties of the alloys can be obtained from Refs. [2,4,11,13] and [11,89,90], respectively. Nevertheless, a short summary of the mechanical properties appears necessary to realize the significant property changes induced by formation of reverted austenite.

As an example, Figure 3 shows the mechanical properties of an $\mathrm{Fe}-16 \mathrm{Cr}-5 \mathrm{Ni}-$ $1 \mathrm{Mo}($ wt.\%) soft martensitic stainless steel (EN 1.4418) at room temperature after $4 \mathrm{~h}$ soaking at various temperatures, adapted from Refs. $[13,14]$. At first the ultimate tensile strength, the $0.2 \%$ yield strength and the hardness increase by heat-treating up to 475 ${ }^{\circ} \mathrm{C}$, which is an effect of secondary hardening from precipitation of $\mathrm{Mo}_{2} \mathrm{C}$. Then softening occurs up to $625{ }^{\circ} \mathrm{C}$, mainly due to austenite reversion and recovery of martensite. A new increase in ultimate tensile strength, $0.2 \%$ yield strength and hardness is observed upon heat treatment at $700{ }^{\circ} \mathrm{C}$ and above, originating from transformation of reverted austenite to fresh martensite and precipitation of $\mathrm{M}_{23} \mathrm{C}_{6}$ carbides. The elongation and impact toughness develop in inverse relation to the ultimate tensile strength, $0.2 \%$ yield strength and hardness with soaking temperature, i.e. are enhanced by reverted austenite formation and recovery of martensite.

In the presence of reverted austenite, soft martensitic and supermartensitic stainless steels show remarkable impact toughness also at sub-zero Celsius temperature 
(>100 $\mathrm{J}$ at $\left.-80{ }^{\circ} \mathrm{C}[11]\right)$. Solheim et al. [91] showed that reverted austenite increased the solubility of hydrogen in supermartensitic stainless steel samples dramatically, and that the ductility of such samples was greatly reduced, suggesting that reverted austenite plays an important role in hydrogen embrittlement.

\section{Critical assessment of compositional data from literature}

All considered references on experimentally determined $\mathrm{Cr}$ and $\mathrm{Ni}$ contents of partitioning in reverted austenite and tempered martensite are sorted in order of ascending annealing temperature in Table 2. Moreover the sample preparation methods and measurement methods, Energy-dispersive X-ray spectroscopy (EDS) in (scanning) transmission electron microscopy ([S]TEM) and atom probe tomography (APT), are indicated. together with the respective measurement and sample preparation methods.
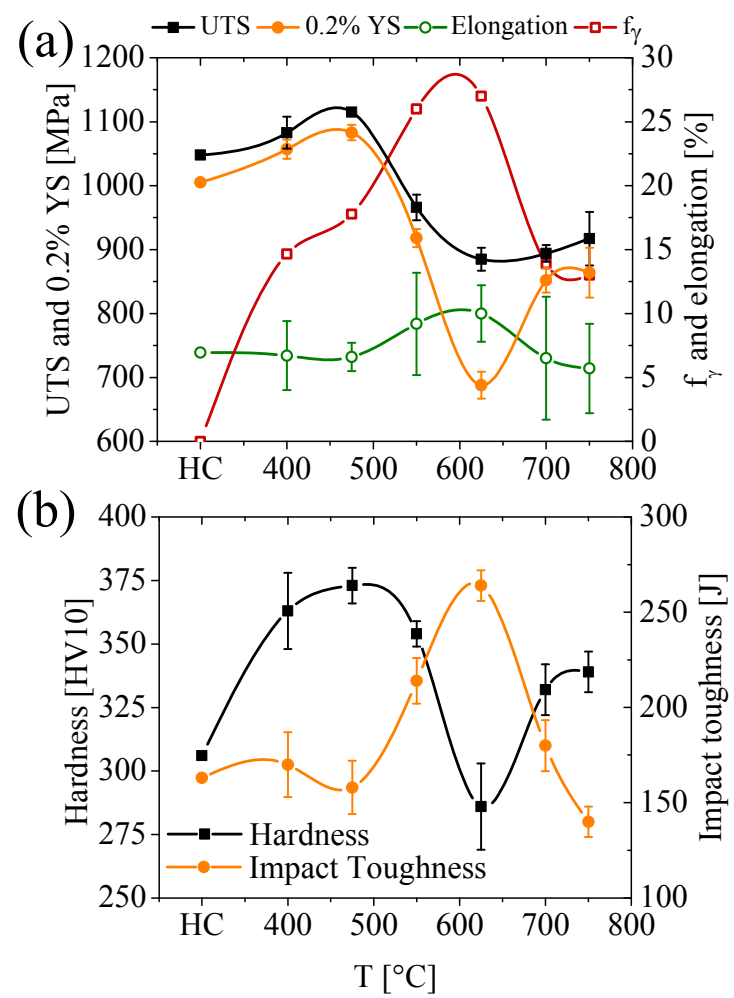

Figure 3. Fraction austenite and mechanical properties of a $16 \mathrm{Cr}-5 \mathrm{Ni}-1 \mathrm{Mo}$ stainless steel at room temperature in the hardened condition (HC) and after $\mathbf{4 h}$ soaking at various temperatures: (a) Ultimate tensile strength (UTS), $0.2 \%$ yield strength (YS), elongation and fraction austenite $\left(f_{\gamma}\right)$; (b) Hardness and Charpy $\mathrm{V}$ impact toughness; The lines are spline functions of measured data (symbols) and do not represent physical values (adapted from Dawood et al. $[13,14]$ ) 
The reported annealing parameters and alloy compositions were used to determine the equilibrium concentrations of $\mathrm{Cr}$ and $\mathrm{Ni}$ in austenite and ferrite by computing phase equilibria (Thermo-Calc 2017a [92] with TCFE6 database [69]). For this purpose, the alloying elements $\mathrm{Cr}, \mathrm{Ni}, \mathrm{Mo}, \mathrm{Mn}, \mathrm{Si}, \mathrm{Cu}, \mathrm{C}$ and $\mathrm{N}$ and the phases fcc, bcc, cementite, $\mathrm{M}_{6} \mathrm{C}, \mathrm{M}_{7} \mathrm{C}_{3}$ and $\mathrm{M}_{23} \mathrm{C}_{6}$ were taken into account, representing the most common elements and phases reported in literature [93].

Figure 4 gives reported $\mathrm{Ni}$ and $\mathrm{Cr}$ concentrations in tempered martensite (a and c) and reverted austenite (b and d) compared with the respective concentrations from computed phase equilibria. Short proximity of data points to the diagonal line indicates good agreement of the measured concentrations with values reflecting thermodynamic equilibrium for the alloy under consideration. Even though different levels of agreement are obtained for different components and phases, experimental data generally seems to agree with calculations from thermodynamics modelling. This supports that austenite reversion occurs mainly by a diffusional mechanism, as potential large strain energies from a displacive transformation are not reflected in the applied thermodynamics model. In tempered martensite, apart from few outliers, both the reported $\mathrm{Ni}$ and $\mathrm{Cr}$ concentrations are in reasonable agreement with predictions from thermodynamics modelling (Figure $4 \mathrm{a}$ and $\mathrm{c}$, respectively). In austenite, apart from a single measurement, all reported $\mathrm{Cr}$ concentrations exceed the concentrations for thermodynamic equilibrium (Figure 4d). The reported Ni concentrations of reverted austenite show poor agreement with calculated thermodynamic equilibrium values (Figure $4 b$ ). In the latter case, data from APT appeared to agree more convincingly with data from thermodynamic equilibria compared to data from (S)TEM-EDS. Within significant scatter a trend is discernible: Predicted concentrations of Ni in austenite by thermodynamics modelling are approx. 2 wt.\% higher than measured concentrations. As the prediction of the $\mathrm{Ni}$ concentration in austenite is most relevant for the stability of austenite, the origin of the discrepancy between experimental and predicted $\mathrm{Ni}$ content should be investigated. The martensite to austenite phase transformation can be (partly) interface-controlled or local equilibrium may be affected by factors as residual stresses, interfacial segregation and precipitation of carbides. Then the $\mathrm{Cr}$ and $\mathrm{Ni}$ concentrations can vary with time before the condition of (local) equilibrium is obtained. In order to investigate, whether the discrepancy between $\mathrm{Ni}$ concentrations from phase equilibria and measurements decreases with approaching equilibration, a criterion was established 


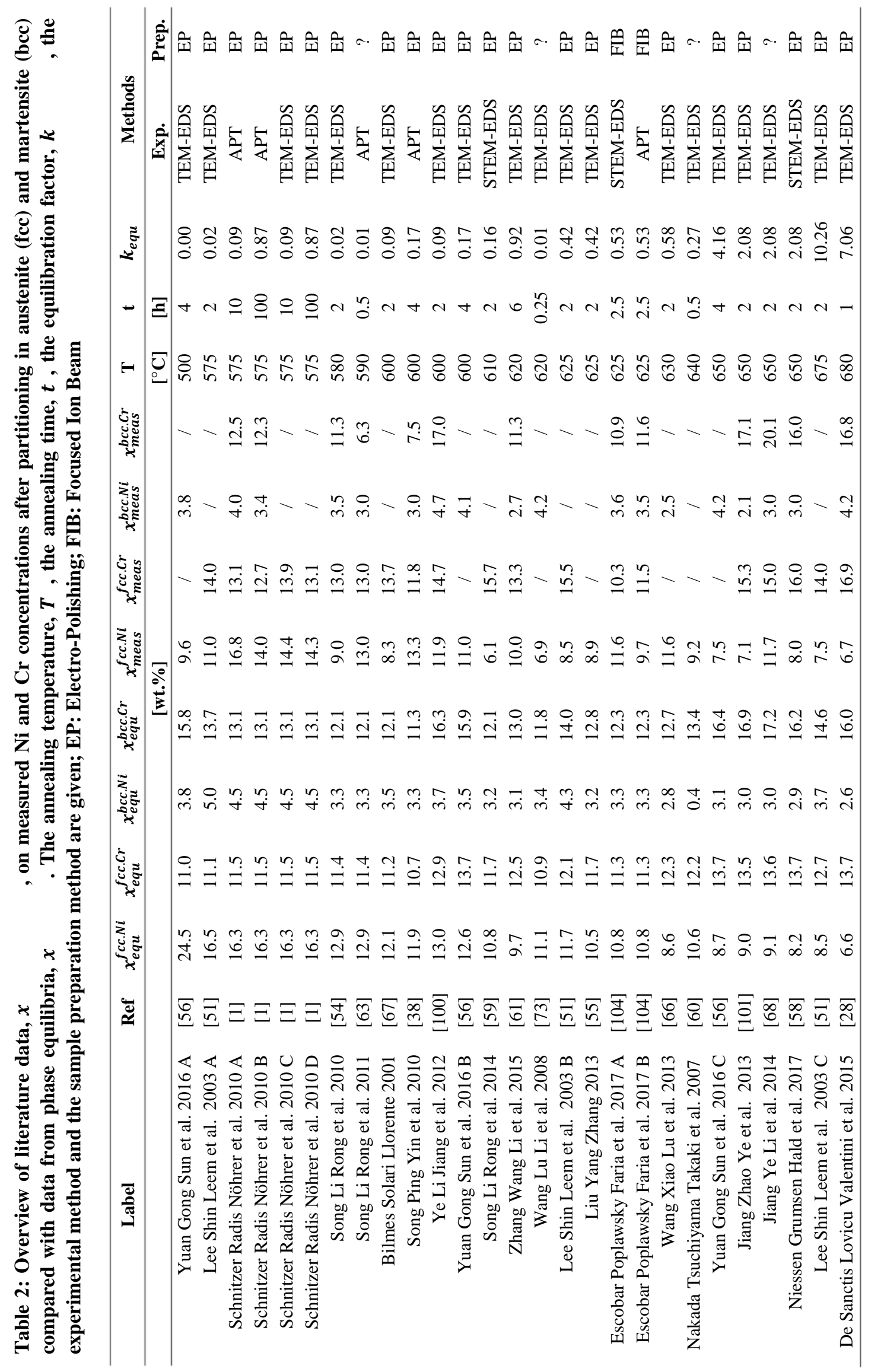



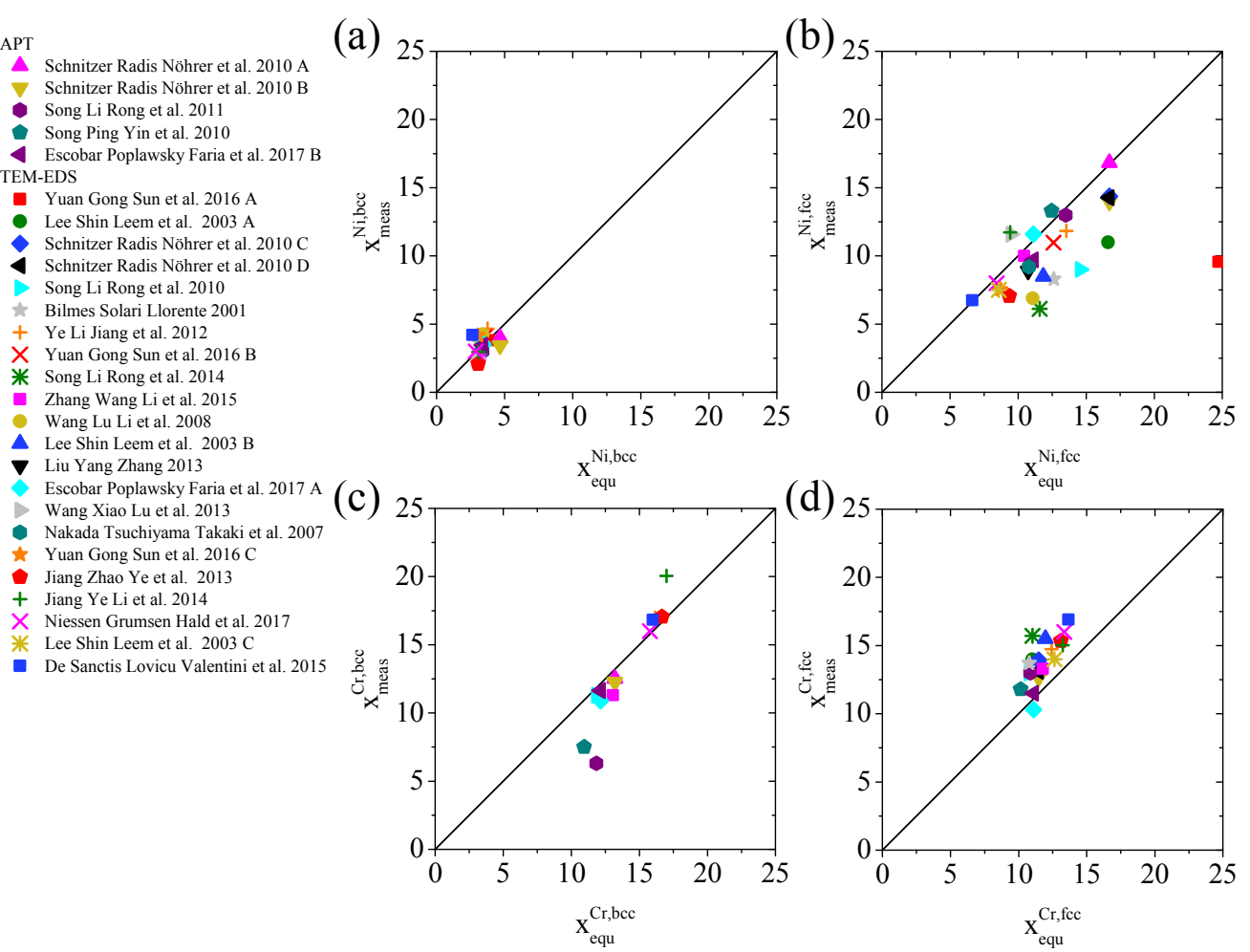

Figure 4. Comparison of the $\mathrm{Ni}$ and $\mathrm{Cr}$ concentrations in tempered martensite (a and c), and reverted austenite (b and d) from EDS and APT analysis, $x_{\text {meas }}$, with data from thermodynamics modelling, $x_{e q u}$, under input of the respective alloy compositions and annealing temperatures; the legend is sorted in order of ascending annealing temperature
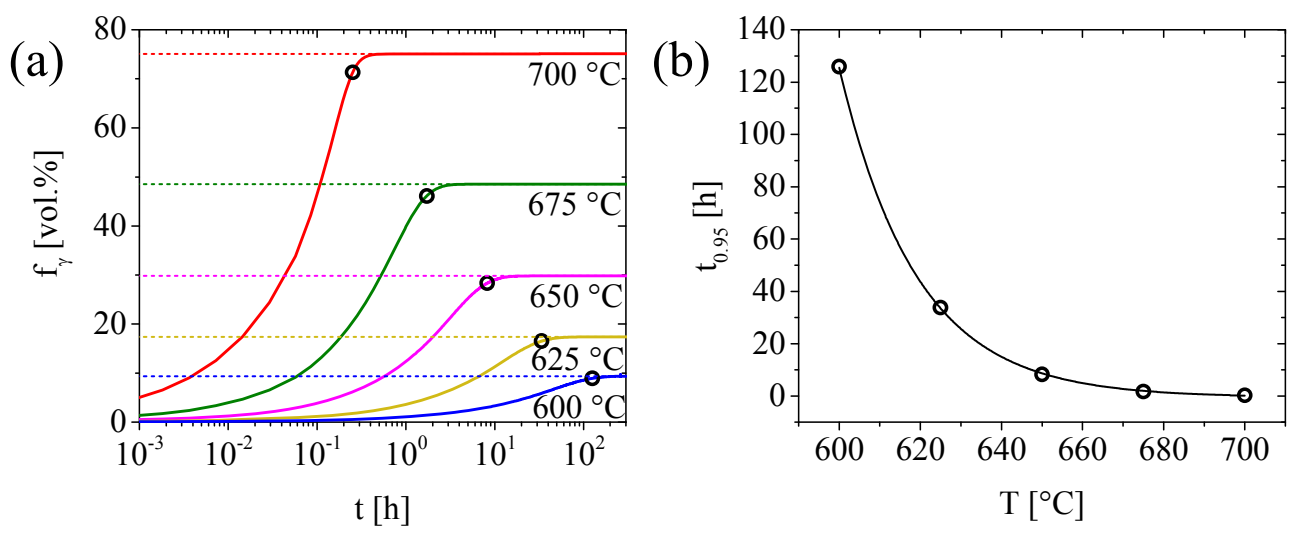

Figure 5. (a) Kinetics of austenite reversion from kinetics modelling of diffusion of a Fe-13.3Cr-5.4Ni (wt.\%) steel (c.f. Figure 2). The broken lines indicate the austenite fractions in equilibrium at the respective temperatures and the open symbols indicate $t_{0.95}$, the time at which $95 \%$ of the equilibrium phase fraction is formed; (b) Fit of $t_{0.95}$ as a function of temperature by an exponential decay function, which is the foundation to assess equilibration of the evaluated heat treatments by the equilibration factor $k_{e q u}(T, t)$. 
to filter the literature data accordingly (Figure 5). For this purpose, the kinetics of forming reverted austenite from a $200 \mathrm{~nm}$ wide martensite lath of an $\mathrm{Fe}-13.3 \mathrm{Cr}-5.4 \mathrm{Ni}$ alloy (c.f. Figure 2) by bulk-diffusion at temperatures between 600 and $700{ }^{\circ} \mathrm{C}$ were assessed in steps of $25{ }^{\circ} \mathrm{C}$ by kinetics modelling of diffusion with DICTRA [94] (see Ref. [27] for further details on the kinetics model). Kinetics modelling assumes purely diffusion controlled martensite-to-austenite transformation and local equilibrium at the martensite/austenite interface [95]. While these assumptions, as discussed above, may not be entirely justified in the present case, kinetics modelling should reliably reflect the general kinetics of austenite reversion in low-carbon martensitic stainless steels at different temperatures to establish a qualitative criterion.

The transformation kinetics in Figure 5a reveals that the time to reach $95 \%$ of the equilibrium fraction $\left(t_{0.95}\right)$ increases from $0.2 \mathrm{~h}$ at $700{ }^{\circ} \mathrm{C}$ to $>100 \mathrm{~h}$ at $600{ }^{\circ} \mathrm{C}$ (see open symbols in Fig. 5a and the temperature dependence in Fig. 5b). The dependence of $t_{0.95}$ on the annealing temperature follows an exponential decay function (Fig. 5b):

$$
t_{0.95}=A \exp \left(\frac{T_{0}-T}{b}\right)+c
$$

with $A=126 \mathrm{~h}, T_{0}=600{ }^{\circ} \mathrm{C}, b=19.1{ }^{\circ} \mathrm{C}$ and $c=-0.5 \mathrm{~h}$.

Comparing the time $t_{0.95}$ at reported temperatures with the respective reported annealing times from literature, a factor $k_{e q u}=t / t_{0.95}$ is obtained to qualitatively estimate the amount of equilibration for each data point (Table 2).

Figure 6 shows the difference of the measured concentrations with respect to concentrations from thermodynamic equilibrium, $\varepsilon$, in austenite as a function of the equilibration factor $k_{e q u}$. Clearly, the difference between the measured and calculated Ni concentration decreases with increasing equilibration (higher $k_{e q u}$ ), while a similar trend, if present at all, is less obvious for Cr. Figure 7 shows the data from Figure 4 after filtering with the equilibration criterion $k_{e q u}>0.1$. As expected from Figure $6 \mathrm{~b}$, the scatter of the $\mathrm{Ni}$ concentration in reverted austenite is reduced, such that the experimental data and data from thermodynamics modelling show reasonable agreement (Figure $7 \mathrm{~b}$ ). Filtering of the data on the $\mathrm{Cr}$ concentration in reverted austenite reduces the scatter to a small extent and further confirms that the $\mathrm{Cr}$ concentration in 
reverted austenite is systematically measured to be $1.0-3.5 \mathrm{wt} \% \%$ higher than predicted by equilibrium thermodynamics (Figure 7d).

\section{Discussion}

\section{Early stage of reverted austenite formation close to $A_{1}$}

Microstructure characterization of the initial stage of reverted austenite formation is difficult to conduct and of more fundamental interest. So far, only limited studies have been conducted on the early stage of austenite formation, while the mechanisms during growth in different temperature regimes are fairly well established. Nevertheless, by studying related alloy systems and carefully interpreting related mechanisms, such as martensite formation and austenite memory, an understanding of the early stage of austenite formation can be acquired from the existing literature.

Raabe et al. [8] observed segregation of Mn up to 24 at.\% at lath boundaries prior to formation of reverted austenite on tempering an Fe-9Mn (at.\%) maraging alloy at $450{ }^{\circ} \mathrm{C}$. The experimentally observed grain boundary enrichment factors, which relate the bulk concentration of an element to the concentration at the grain boundary, were found similar for $\mathrm{Mn}$ and $\mathrm{Ni}$ [8]. Thus, $\mathrm{Ni}$ is likely to segregate to lath boundaries in low-carbon martensitic stainless steel during heating which would locally increase
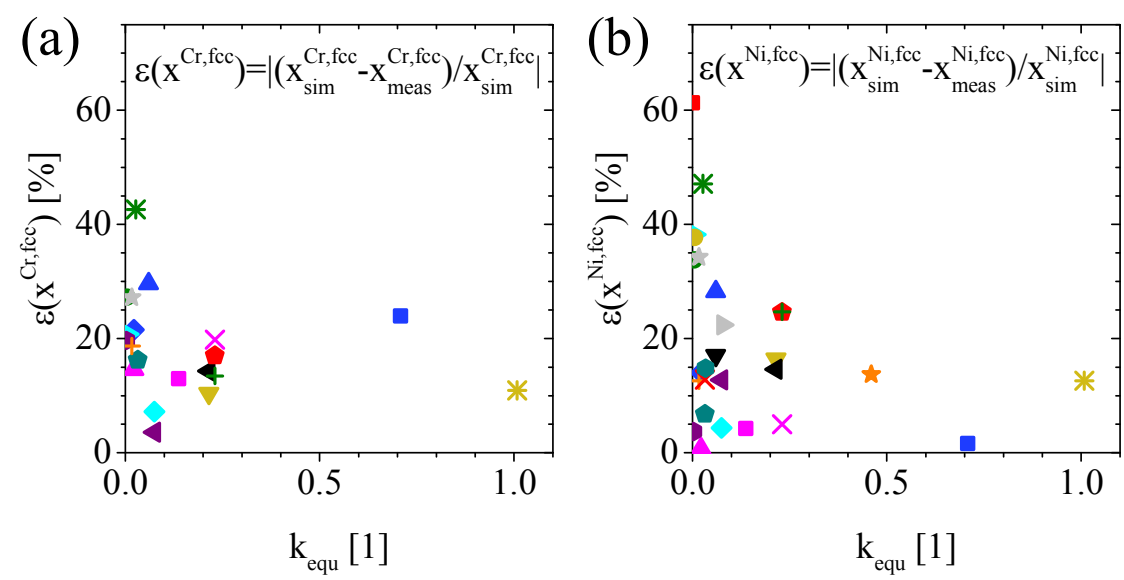

Figure 6. Difference of measured concentrations with respect to concentrations from thermodynamic equilibrium, $\varepsilon$, as a function of the equilibration factor $\boldsymbol{k}_{\boldsymbol{e}} \boldsymbol{u}$ (Figure 5b) of the (a) $\mathrm{Cr}$ and (b) Ni concentration in reverted austenite. The symbols correspond to the legend in Figure 4. 
the driving force for austenite formation and thereby aid austenite nucleation. So far, no experimental evidence of such mechanisms has been reported that can corroborate this hypothesis.

Stress plays a fundamental role in martensite formation. The strict hierarchy of lath martensite follows the minimisation of the total shape strain [96]. It therefore appears unavoidable to consider the role of stress in the reverted transformation to austenite. The previously mentioned austenite memory effect, the strong tendency of reverted austenite to form in an identical crystallographic orientation to the prior austenite grain, gives important insight into the role of stress in the early stage of reverted austenite formation. Nakada et al. [64] suggested that the reverted austenite variants are theoretically limited to two variants within a martensite packet: the prior austenite and a twin-related orientation variant. The variant restriction originates from crystal symmetry and considerations of interfacial energies and was validated with experiments on a supermartensitic stainless steel with no retained austenite. Indeed, only the two predicted variants formed. Interestingly, the twin-related variant made up
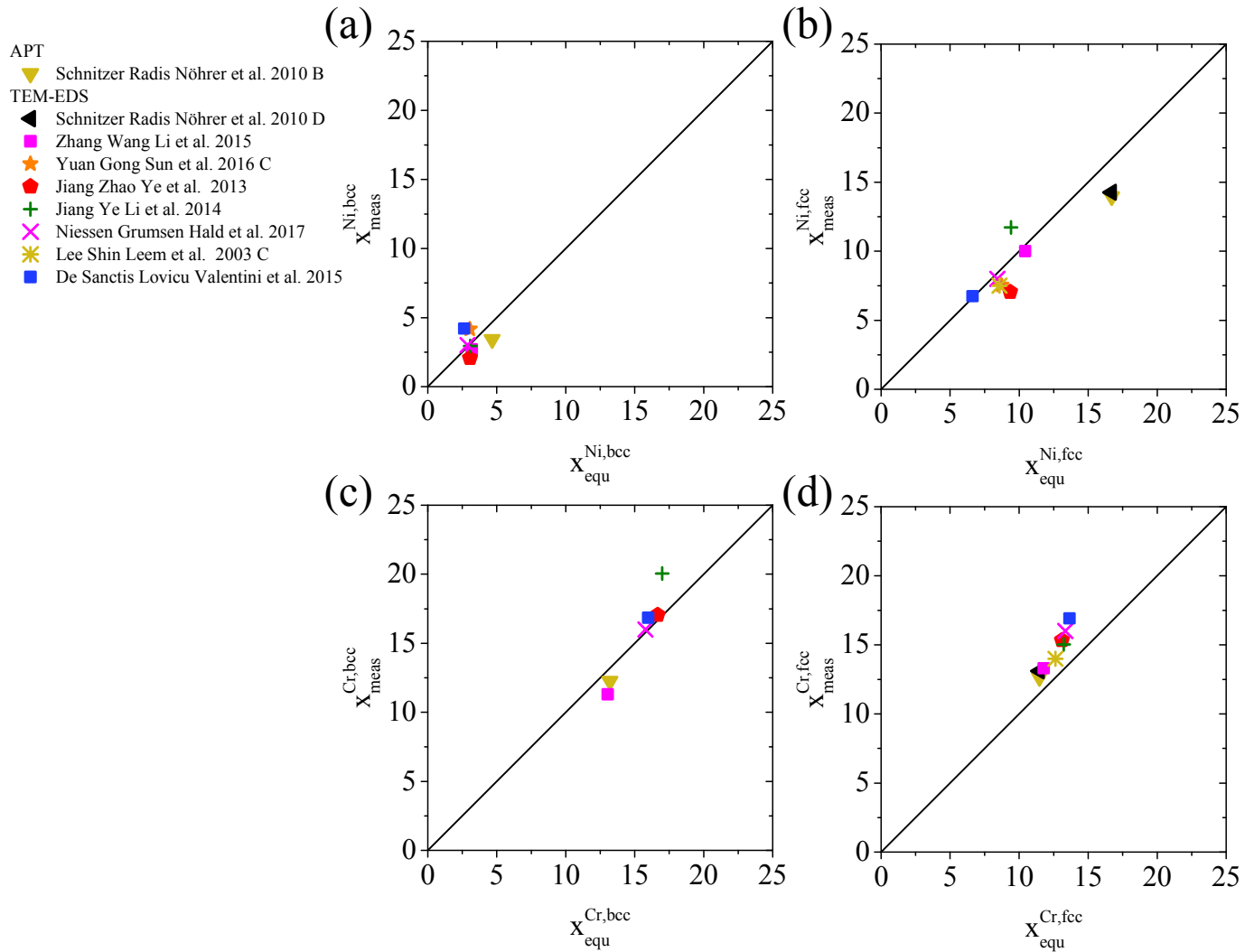

Figure 7. Comparison of the $\mathrm{Ni}$ and $\mathrm{Cr}$ concentrations in tempered martensite (a and $c$ ), and reverted austenite (b and $d$ ) with data from thermodynamics modelling from Figure 4 for data with an equilibration factor of $k_{e q u}>0.1$. 
less than $5 \%$ area fraction of reverted austenite and could be increased to approx. $40 \%$ by applying a uniaxial tensile stress of $100 \mathrm{MPa}$ during inter-critical annealing. As a consequence, Nakada et al. suggested that also residual stress affects austenite memory in that it favours the prior austenite orientation [64].

Miyamoto et al. [97] provided experimental evidence of the accommodation of transformation strains from lath martensite formation in austenite by measurement of lattice strains (rotations). Sandvik et al. [34] suggested plastic accommodation of transformation strains in martensite laths by characterising the dislocation substructure. Both independently reported that the martensite/austenite interface is relatively straight on one side and irregular on the other side of a lath (Figure 8), which suggests thickening of martensite laths mainly towards the irregular side of the interface. Consequently, transformation strains should accumulate with movement of the martensite/austenite interface and manifest as build-up of residual stress between adjacent laths.

When annealing lath martensite, austenite formation in a crystallographically reverse sense with respect to martensite formation, i.e. an inverse interface movement and orientation relationship, should lead to relaxation of these stresses. Residual stress between adjacent laths may thus act as a mechanical driving force that, in addition to

(a)

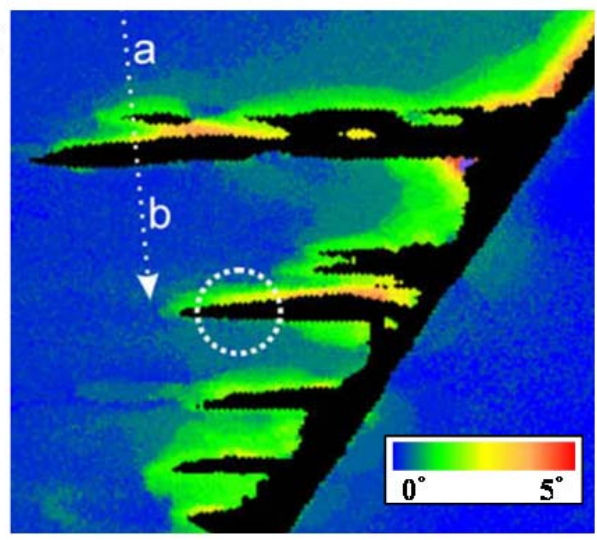

(b)

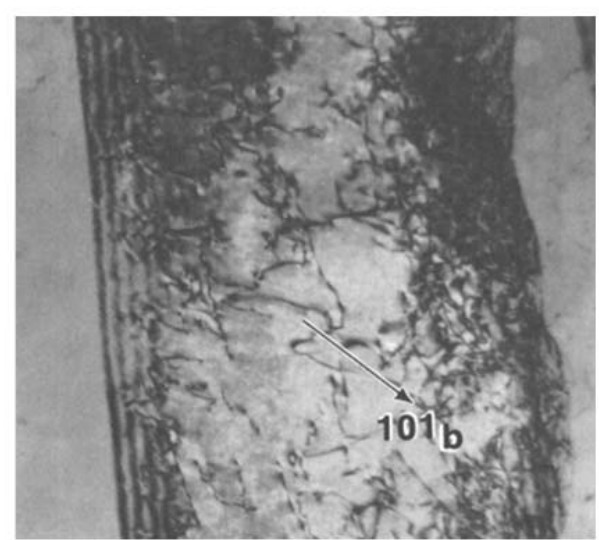

Figure 8. Footage from literature indicating thickening of lath martensite to primarily one side; (a) Misorientation map of austenite from electron backscatter diffraction (EBSD) after growth of lath martensite (black) in an Fe20Ni-5Mn (wt.\%) alloy indicating strain accommodation of the transformation strain in austenite in primarily one direction of the lath (Ref. [97], permission was automatically granted according to the STM signatory guidelines.); (b) Example of a martensite lath in an Fe-20Ni-6Mn-0.01 (wt.\%) alloy, showing a relatively straight (left side) and irregular (right side) martensite/austenite interface (Ref. [34], RightsLink license number 4294080199168.); 
the chemical driving force, promotes formation and diffusional growth of austenite in a distinct orientation and growth direction. The observed formation of austenite in only one lath of at lath boundary below $575{ }^{\circ} \mathrm{C}$ is consistent with this hypothesis (Figure 1a) $[1,55,60,63]$. At sufficiently high temperature, recovery of martensite partially relaxes the residual stress and the chemical driving force for austenite formation is higher. Consequently, the contribution of the mechanical driving force is greatly reduced, which gives a consistent explanation for austenite formation in both laths of a lath boundary above $575^{\circ} \mathrm{C}$ (Figure 1b) [55,58,60]. Further evidence from experiments and modelling is required to corroborate this hypothesis.

\section{Discrepancy of data on solute partitioning from equilibrium calculations and literature}

While reasonable agreement of concentrations from literature data with concentrations from thermodynamic equilibrium was obtained for $\mathrm{Cr}$ and $\mathrm{Ni}$ in martensite (ferrite), in austenite systematic and more random discrepancies were found for $\mathrm{Cr}$ and $\mathrm{Ni}$, respectively. In the following, possible reasons will be discussed.

At first, it is noted that the calculated thermodynamic equilibria originate from a modelling method, which inherently suffers from uncertainties originating from databases [98] and relies on extrapolation from constituent subsystems to multicomponent alloy systems $[99,100]$. In the present case, further uncertainties are expected from treating all alloys with the same list of phases and components, where in some cases not all components were reported or included. Considering these uncertainties, the observed amount of systematic deviation (approx. 2 wt.\% for $\mathrm{Cr}$ in martensite) appears too excessive to be introduced by the CALPHAD method or the database. The analysed Fe-Cr-Ni alloy system is amongst the best-described systems in thermodynamics modelling and has proven to provide excellent predictions in previous cases [101-103]. Moreover, it appears difficult to explain the more random deviation of $\mathrm{Ni}$ in austenite with potential uncertainties in the CALPHAD method. Therefore other reasons for the observed deviation need consideration.

According to thermodynamic equilibrium, $\mathrm{Cr}$ is in all analysed cases supposed to be rejected from austenite and dissolved in carbides and martensite during intercritical annealing. The difference in concentration between austenite and martensite should in average amount to 2 wt.\% (Table 2). From 13 experimental datasets on 
partitioning of $\mathrm{Cr}$ in austenite and martensite, only three datasets qualitatively confirm such partitioning $[73,104,105]$, while six datasets show no partitioning within 0.5 wt.\% of accuracy $[1,33,62,66]$ and four datasets (all originating from the same research group) even show inverse partitioning, i.e. Cr-enrichment in austenite $[41,58,65,67]$. Even though these inconsistent observations are difficult to interpret, it appears likely that growth of $\mathrm{M}_{23} \mathrm{C}_{6}$ carbides affects the local $\mathrm{Cr}$ contents of austenite and martensite. $\mathrm{M}_{23} \mathrm{C}_{6}$ carbides share a coherent interface with reverted austenite, which is anticipated to facilitate the diffusion flux of $\mathrm{Cr}$ and $\mathrm{Ni}$ during diffusion accompanied growth of both phases, as also suggested in Ref. [65].

In contrast to the $\mathrm{Cr}$ concentration, the $\mathrm{Ni}$ concentration in austenite deviated more randomly from thermodynamic equilibrium (Figure $4 \mathrm{~b}$ ). Within large scatter, Ni was in average predicted with 2 wt.\% higher concentration than characterized in literature. It appears that two major effects cause the discrepancy: insufficient equilibration of the microstructure and experimental error.

It was found that the $\mathrm{Ni}$ concentration in austenite can be predicted with reasonable accuracy by phase equilibria when the microstructure approaches equilibration (higher $k_{e q u}$ in Figure 6b). Escobar et al. [66] reported that, even when the equilibrium phase fraction was obtained after annealing for $2.5 \mathrm{~h}$ at $625{ }^{\circ} \mathrm{C}$, individual austenite lamellae revealed approx. \pm 2 wt.\% difference in Ni concentration. Further, gradients of $\mathrm{Ni}$ concentration within austenite lamellae in the range of approx. 4 wt.\% from interface to bulk were measured with APT. Apparently, the initial composition of reverted austenite is far from equilibrium.

It is noted that martensite itself must be considered as metastable ferrite, as it deviates from ferrite in thermodynamic equilibrium. Nucleation of reverted austenite in equilibrium with martensite (metastable ferrite) may thus occur with different phase compositions as predicted for austenite and ferrite in thermodynamic equilibrium. It is suggested that the phase fractions and compositions of austenite and martensite during continued annealing evolve towards global equilibrium, which appears to be a slow and complex process.

The majority of insufficiently equilibrated microstructures $\left(k_{e q u}<0.1\right)$ were obtained from annealing below $650{ }^{\circ} \mathrm{C}$. As partitioning of $\mathrm{Ni}$ increases with lower temperature (Figure 2), sharp compositional measurements over thin austenite films (40 $-150 \mathrm{~nm}$ width) and tempered martensite become more challenging. Figure 4 reveals 
that measurements from APT matched the predictions from thermodynamic equilibrium more convincingly than measurements from (S)TEM-EDS. As the spatial resolution (near atomic) and compositional resolution (few ppm) of APT are by far superior to that of standard (S)TEM-EDS [106], this observation appears reasonable. (S)TEM-EDS faces the inherent issue of insufficient counting rate when samples are too thin, leading to insufficient compositional accuracy when applying low counting times and contamination and beam drift when applying high counting times [107]. Increasing the sample thickness on the other hand reduces the spatial resolution and complicates measurement of a sharp austenite/martensite interface. Reliable measurements of finegrained and partitioned microstructures are certainly possible (good agreement with data from APT was for instance obtained in Refs. [1,66]), but several potential error sources render data from EDS generally less trustworthy. The lower experimentally determined Ni-concentrations, especially at lower temperature, may therefore to a certain extent originate from a higher experimental error of (S)TEM-EDS measurements.

\section{Conclusions}

The mechanism of austenite reversion in low-carbon martensitic stainless steels was critically reviewed by collating literature on nucleation and growth, stability against martensite formation and the effect on microstructure properties of reverted austenite. Discussion of the morphology of austenite films close to $A_{1}$ in the light of austenite memory and the mechanism of martensite formation led to suggest that residual stresses from the martensite microstructure aid nucleation of reverted austenite close to $\mathrm{A}_{1}$. It was further investigated whether literature data on the $\mathrm{Ni}$ and $\mathrm{Cr}$ concentrations in austenite and martensite after inter-critical annealing comply with thermodynamic equilibrium from thermodynamics modelling. In martensite, measured $\mathrm{Cr}$ and $\mathrm{Ni}$ concentrations matched predictions from thermodynamics modelling with reasonable accuracy. Systematic excess of $\mathrm{Cr}$ in austenite by approx. $2 \mathrm{wt} . \%$ relative to predictions was suspected to originate from growth of $\mathrm{M}_{23} \mathrm{C}_{6}$ with a coherent interface to austenite. Within large scatter, measured values of $\mathrm{Ni}$ in austenite were in average $2 \mathrm{wt} . \%$ below predictions from thermodynamics modelling. The scatter reduced dramatically when only microstructures with advanced equilibration were considered. Further, APT data matched predictions more convincingly than data from (S)TEM-EDS, indicating better 
experimental accuracy for determining concentrations in the partitioned microstructure.

\section{Acknowledgements}

The Danish Underground Consortium is gratefully acknowledged for financial support to the Danish Hydrocarbon Research Center. The author is grateful to Prof. Marcel A.J. Somers and Prof. John Hald, Department of Mechanical Engineering at the Technical University of Denmark, for fruitful discussions and proofreading of the manuscript. 


\section{References}

[1] Schnitzer R, Radis R, Nöhrer M, Schober M, Hochfellner R, Zinner S, PovodenKaradeniz E, Kozeschnik E and Leitner H. Reverted austenite in PH 13-8 Mo maraging steels. Mater. Chem. Phys. 2010;122:138-145.

[2] Niederau HJ. Eigenschaften und Anwendungsmöglichkeiten der Guss- und Schmiedelegierung (G)X-5 CrNiMo 165 (Werkstoff-Nr. 1.4405). Zeitschrift des Vereins Dtsch. Ingenieure für Maschinenbau und Met. Eig. 1982;21:801-808.

[3] Grounes M and Rao S. New Alloy Steels for Nuclear Reactor Pressure Vessels and Vessel Internals. Trans. ASM. 1969;62:902-914.

[4] Brezina P and Sonderegger B. Wärmebehandlung, Gefüge und Eigenschaften des korrosionsträgen martensitaushärtbaren Stahles X 5 CrNiMoCuNb 145 (14-5 PU). Härterei-Technische Mitteilungen. 1978;33:1-12.

[5] Tomimura K, Takaki S, Tanimoto S and Tokunaga Y. Optimal Chemical Composition in Fe-Cr-Ni Alloys for Ultra Grain Refining by Reversion from Deformation Induced Martensite. ISIJ Int. 1991;31:721-727.

[6] Tomimura K, Takaki S and Tokunaga Y. Reversion Mechanism from Deformation Induced Martensite to Austenite in Metastable Austenitic Stainless Steels. ISIJ Int. 1991;31:1431-1437.

[7] Kuzmina M, Ponge D and Raabe D. Grain boundary segregation engineering and austenite reversion turn embrittlement into toughness: Example of a 9 wt.\% medium Mn steel. Acta Mater. 2015;86:182-192.

[8] Raabe D, Sandlöbes S, Millán J, Ponge D, Assadi H, Herbig M and Choi PP. Segregation engineering enables nanoscale martensite to austenite phase transformation at grain boundaries: A pathway to ductile martensite. Acta Mater. 2013;61:6132-6152.

[9] Irvine KJ, Crowe DJ and Pickering FB. The physical metallurgy of $12 \%$ chromium steels. J. Iron Steel Inst. 1960;193:386-406.

[10] Kondo K, Ueda M, Ogawa K, Hirata H, Takabe H and Miyazaki Y. Alloy design of Super 13Cr martensitic stainless steel. Supermartensitic Stainl. Steels 1999. 1999. p. 11-18. 
[11] Marshall AW and Farrar JCM. Welding of Ferritic and Martensitic 11-14\% Cr Steels. Weld. World. 2001;45:19-42.

[12] Karlsson L, Rigdal S, Bruins W and Goldschmitz M. Development of matching composition supermartensitic stainless steel welding consumables. Svetsaren. 1999;54:3-7.

[13] Al Dawood M, El Mahallawi IS, Abd El Azim ME and El Koussy MR. Thermal aging of $16 \mathrm{Cr}-5 \mathrm{Ni}-1 \mathrm{Mo}$ stainless steel Part 1 - Microstructural analysis. Mater. Sci. Technol. 2004;20:363-369.

[14] Al Dawood M, El Mahallawi IS, Abd El Azim ME and El Koussy MR. Thermal aging of $16 \mathrm{Cr}-5 \mathrm{Ni}-1 \mathrm{Mo}$ stainless steel Part 2 - Mechanical property characterisation. Mater. Sci. Technol. 2004;20:370-374.

[15] Sagara M, Yamada K, Taniyama A, Ogawa K, Motoya D, Takabe H, Amaya H and Ueda M. Development for Material and Application Technique of Stainless Steel Line Pipes. Nippon Steel Sumitomo Met. Tech. Rep. 2015;59-64.

[16] Tvrdy M, Vodarek V, Roznovska G, Korcak A, Seliga J, Barta J and Tkacik P. Production, development and industrial application of $12 \mathrm{Cr}-6 \mathrm{Ni}-2.5 \mathrm{Mo}$ steels. Supermartensitic Stainl. Steels 2002 Brussels. 2002. p. 29-33.

[17] Toussaint P and Dufrane J-J. Advances in the making and base material properties of supermartensitic stainless steels (SMSS). Supermartensitic Stainl. Steels 2002 Brussels. KCI Publishing; 2002. p. 23-27.

[18] Baggström G. New Steel for Turbine Runners. Water Power. 1964;16:516-521.

[19] Grounes M. Swedish Work on Brittle-Fracture Problems in Nuclear Reactor Pressure Vessels. AB Atomenergi, Sweden. 1966;1-34.

[20] Grounes M and Lindhagen P. Irradiation Effects in Pressure Vessel Materials for Steam-Cooled Fast Reactors. Irradiat. Eff. Struct. Alloy. Therm. Fast React. ASTM STP 457. 1969. p. 156-179.

[21] Servant C, Gherbi EH and Cizeron G. TEM investigation of the tempering behaviour of the maraging PH 17.4 Mo stainless steel. J. Mater. Sci. 1987;22:2297-2304.

[22] Morley JI. Some recent developments in stainless steels. Iron Steel. 
$1955 ; 28: 183-188$.

[23] Kondo K, Ogawa K, Amaya A, Ueda M and Ohtani H. Development of Weldable Super 13Cr Martensitic Stainless Steel for Flowline. Proc. Twelfth Int. Offshore Polar Eng. Conf. 2002. p. 303-309.

[24] Van der Winden H, Toussaint P and Coudreuse L. Past, present and future of weldable supermartensitic alloys. Supermartensitic Stainl. Steels 2002 Brussels. 2002. p. 9-13.

[25] Kvaale PE and Stein O. Experience with supermartensitic stainless steels in flowline applications. Stainl. Steel World 99. 1999. p. 19-26.

[26] Ma X, Wang L, Subramanian S V. and Liu C. Studies on Nb microalloying of $13 \mathrm{Cr}$ super martensitic stainless steel. Metall. Mater. Trans. A Phys. Metall. Mater. Sci. 2012;43:4475-4486.

[27] Niessen F, Villa M, Hald J and Somers MAJ. Kinetics analysis of two-stage austenitization in supermartensitic stainless steel. Mater. Des. 2017;116:8-15.

[28] Villa M, Pantleon K, Reich M, Kessler O and Somers MAJ. Kinetics of anomalous multi-step formation of lath martensite in steel. Acta Mater. $2014 ; 80: 468-477$.

[29] Hsiao CN, Chiou CS and Yang JR. Aging reactions in a 17-4 PH stainless steel. Mater. Chem. Phys. 2002;74:134-142.

[30] Niessen F, Villa M, Apel D, Keßler O, Reich M, Hald J and Somers MAJ. In situ techniques for the investigation of the kinetics of austenitization of supermartensitic stainless steel. Mater. Sci. Forum. 2017;879:1381-1386.

[31] Bojack A, Zhao L, Morris PF and Sietsma J. In-situ determination of austenite and martensite formation in $13 \mathrm{Cr} 6 \mathrm{Ni} 2 \mathrm{Mo}$ supermartensitic stainless steel. Mater. Charact. 2012;71:77-86.

[32] Rodrigues CAD, Lorenzo PLD, Sokolowski A, Barbosa CA and Rollo JMDA. Titanium and molybdenum content in supermartensitic stainless steel. Mater. Sci. Eng. A. 2007;460-461:149-152.

[33] De Sanctis M, Lovicu G, Valentini R, Dimatteo A, Ishak R, Migliaccio U, Montanari R and Pietrangeli E. Microstructural Features Affecting Tempering 
Behavior of $16 \mathrm{Cr}-5 \mathrm{Ni}$ Supermartensitic Steel. Metall. Mater. Trans. A Phys. Metall. Mater. Sci. 2015;46:1878-1887.

[34] Sandvik BPJ and Wayman CM. Characteristics of Lath Martensite: Part I. Crystallographic and Substructural Features. Metall. Trans. A. 1983;14:809-822.

[35] Kurdjumow G and Sachs G. Über den Mechanismus der Stahlhärtung. Zeitschrift für Phys. 1930;64:325-343.

[36] Bos C, Sietsma J and Thijsse BJ. Molecular dynamics simulation of interface dynamics during the fcc-bcc transformation of a martensitic nature. Phys. Rev. B - Condens. Matter Mater. Phys. 2006;73:1-7.

[37] Maresca F and Curtin WA. The austenite/lath martensite interface in steels: Structure, athermal motion, and in-situ transformation strain revealed by simulation and theory. Acta Mater. 2017;134:302-323.

[38] Bhadeshia HKDH. Worked examples in the geometry of crystals. 2nd editio. 2001.

[39] Hall MG, Aaronson HI and Kinsma KR. The structure of nearly coherent fcc: bcc boundaries in a CuCr alloy. Surf. Sci. 1972;31:257-274.

[40] Niessen F, Danoix F, Hald J and Somers MAJ. Structural analysis in atom probe tomography - application to tempering of supermartensitic stainless steel. 7th Eur. Atom Probe Work. 2017, Gullmarsstrand, Sweden. 2017.

[41] Song Y, Ping DH, Yin FX, Li XY and Li YY. Microstructural evolution and low temperature impact toughness of a $\mathrm{Fe}-13 \% \mathrm{Cr}-4 \% \mathrm{Ni}-\mathrm{Mo}$ martensitic stainless steel. Mater. Sci. Eng. A. 2010;527:614-618.

[42] Villa M, Niessen F and Somers MAJ. In situ investigation of the evolution of lattice strain and stresses in austenite and martensite during quenching and tempering of steel. Metall. Mater. Trans. A. 2017;49:1-13.

[43] Maki T. Morphology and substructure of martensite in steels. In: Pereloma E, Edmonds D V., editors. Phase Transform. steels Vol. 2 Diffus. Transform. High Strength Steels, Model. Adv. Anal. Tech. 1st ed. Woodhead Publishing; 2012. p. 34-58.

[44] Christien F, Telling MTF and Knight KS. Neutron diffraction in situ monitoring 
of the dislocation density during martensitic transformation in a stainless steel. Scr. Mater. 2013;68:506-509.

[45] Wiessner M, Gamsjäger E, van der Zwaag S and Angerer P. Effect of reverted austenite on tensile and impact strength in a martensitic stainless steel-An in-situ X-ray diffraction study. Mater. Sci. Eng. A. 2017;682:117-125.

[46] Speich GR. Tempering of Low-Carbon Martensite. Trans. Metall. Soc. AIME. $1969 ; 245: 2553-2564$.

[47] Slunder CJ, Hoenie AF and Hall AM. Thermal and Mechanical Treatment for Precipitation-Hardening Stainless Steels. NASA, Washingt. D.C. 1967.

[48] Ludwigson DC and Hall AM. The physical metallurgy of precipitationhardenable stainless steels, DMIC Report 111, Battelle Mem. Inst., Columbus, OH,. 1959.

[49] Yeli G, Auger MA, Smith GDW, Bagot AJ, Moody MP, Bagot PAJ, Moody MP, Bagot AJ and Moody MP. Atom Probe Tomography (APT) characterization of the sequence of phase nucleation in a 17-4PH steel. Proc. Int. Conf. Solid-Solid Phase Transform. Inorg. Mater. 2015. 2015. p. 167-168.

[50] Yeli G, Auger MA, Wilford K, Smith GDW, Bagot PAJ and Moody MP. Sequential nucleation of phases in a 17-4PH steel: Microstructural characterisation and mechanical properties. Acta Mater. 2017;125:38-49.

[51] Li T, Ahmed M, Sha G, Shi R, Casillas G, Yen HWHWHWHWHWHW, Wang Y, Pereloma EVEVEVE V. and Cairney JM. The influence of partitioning on the growth of intragranular alpha in near-beta Ti alloys. J. Alloys Compd. [Internet]. $2015 ; 643: 212-222$.

[52] Bojack A, Zhao L, Morris PF and Sietsma J. Austenite Formation from Martensite in a $13 \mathrm{Cr} 6 \mathrm{Ni} 2 \mathrm{Mo}$ Supermartensitic Stainless Steel. Metall. Mater. Trans. A. 2016;47:1996-2009.

[53] Ma XP, Wang LJ, Qin B, Liu CM and Subramanian SV. Effect of N on microstructure and mechanical properties of $16 \mathrm{Cr} 5 \mathrm{Ni1Mo}$ martensitic stainless steel. Mater. Des. 2012;34:74-81.

[54] Leem D-S, Lee Y-D, Jun J-H and Choi C-S. Amount of retained austenite at room temperature after reverse transformation of martensite to austenite in an 
Fe-13\%Cr-7\%Ni-3\%Si martensitic stainless steel. Scr. Mater. 2001;45:767772.

[55] Lee Y-K, Shin H-C, Leem D-S, Choi J-Y, Jin W and Choi C-S. Reverse transformation mechanism of martensite to austenite and amount of retained austenite after reverse transformation in $\mathrm{Fe}-3 \mathrm{Si}-13 \mathrm{Cr}-7 \mathrm{Ni}(\mathrm{wt}-\%)$ martensitic stainless steel. Mater. Sci. Technol. 2003;19:393-398.

[56] Nakada N, Tsuchiyama T, Takaki S and Miyano N. Temperature Dependence of Austenite Nucleation Behavior from Lath Martensite. ISIJ Int. 2011;51:299-304.

[57] Liu L, Yang ZG, Zhang C and Liu WB. An in situ study on austenite memory and austenitic spontaneous recrystallization of a martensitic steel. Mater. Sci. Eng. A. 2010;527:7204-7209.

[58] Song YY, Li XY, Rong LJ, Ping DH, Yin FX and Li YY. Formation of the reversed austenite during intercritical tempering in a $\mathrm{Fe}-13 \% \mathrm{Cr}-4 \% \mathrm{Ni}-\mathrm{Mo}$ martensitic stainless steel. Mater. Lett. 2010;64:1411-1414.

[59] Liu L, Yang Z-G and Zhang C. Effect of retained austenite on austenite memory of a 13\% Cr-5\% Ni martensitic steel. J. Alloys Compd. 2013;577:654-660.

[60] Yuan WH, Gong XH, Sun YQ and Liang JX. Microstructure Evolution and Precipitation Behavior of 0Cr16Ni5Mo Martensitic Stainless Steel during Tempering Process. J. Iron Steel Res. Int. 2016;23:401-408.

[61] Morito S, Tanaka H, Konishi R, Furuhara T and Maki T. The morphology and crystallography of lath martensite in Fe-C alloys. Acta Mater. 2003;51:17891799.

[62] Niessen F, Grumsen FB, Hald J and Somers MAJ. Formation and stabilization of reversed austenite in supermartensitic stainless steel. Proc. 24th IFHTSE Congr. 2017. p. 138-145.

[63] Song YY, Li XY, Rong LJ, Li YY and Nagai T. Reversed austenite in 0Cr13Ni4Mo martensitic stainless steels. Mater. Chem. Phys. 2014;143:728-734.

[64] Nakada N, Tsuchiyama T, Takaki S and Hashizume S. Variant Selection of Reversed Austenite in Lath Martensite. ISIJ Int. 2007;47:1527-1532.

[65] Zhang S, Wang P, Li D and Li Y. Investigation of the evolution of retained 
austenite in $\mathrm{Fe}-13 \% \mathrm{Cr}-4 \% \mathrm{Ni}$ martensitic stainless steel during intercritical tempering. Mater. Des. 2015;84:385-394.

[66] Escobar JD, Poplawsky JD, Faria GA, Rodriguez J, Oliveira JP, Salvador CAF, Mei PR, Babu SS and Ramirez AJ. Compositional analysis on the reverted austenite and tempered martensite in a Ti-stabilized supermartensitic stainless steel: Segregation, partitioning and carbide precipitation. Mater. Des. 2018;140:95-105.

[67] Song Y, Li X, Rong L and Li Y. The influence of tempering temperature on the reversed austenite formation and tensile properties in $\mathrm{Fe}-13 \% \mathrm{Cr}-4 \% \mathrm{Ni}-\mathrm{Mo}$ low carbon martensite stainless steels. Mater. Sci. Eng. A. 2011;528:4075-4079.

[68] Escobar JD, Faria G, Wu L, Oliveira JP, Mei PR and Ramirez AJ. Austenite reversion kinetics and stability during tempering of a Ti-stabilized supermartensitic stainless steel: correlative in situ synchrotron x-ray diffraction and dilatometry. Acta Mater. 2017;

[69] Thermo-Calc Software TCFE6 Steels/Fe-alloys database version 6.2. ThermoCalc Softw. TCFE6 Steels/Fe-alloys database version 6.2 (accessed Novemb. 2009). Thermo-Cal.

[70] Song Y, Li X, Rong L and Li Y. Anomalous Phase Transformation from Martensite to Austenite in Fe-13\%Cr-4\%Ni-Mo Martensitic Stainless Steel. J. Mater. Sci. Technol. 2010;26:823-826.

[71] Wang P, Xiao N, Lu S, Li D and Li Y. Investigation of the mechanical stability of reversed austenite in $13 \% \mathrm{Cr}-4 \% \mathrm{Ni}$ martensitic stainless steel during the uniaxial tensile test. Mater. Sci. Eng. A. 2013;586:292-300.

[72] Bilmes PD, Solari M and Llorente CL. Characteristics and effects of austenite resulting from tempering of $13 \mathrm{Cr}-\mathrm{NiMo}$ martensitic steel weld metals. Mater. Charact. 2001;46:285-296.

[73] Jiang W, Ye D, Li J, Su J and Zhao K. Reverse Transformation Mechanism of Martensite to Austenite in 00Cr15Ni7Mo2WCu2 Super Martensitic Stainless Steel. Steel Res. Int. 2014;85:1150-1157.

[74] Bojack A, Zhao L, Morris PF and Sietsma J. In Situ Thermo-magnetic Investigation of the Austenitic Phase During Tempering of a 13Cr6Ni2Mo 
Supermartensitic Stainless Steel. Metall. Mater. Trans. A Phys. Metall. Mater. Sci. 2014;45:5956-5967.

[75] García-Junceda A, Capdevila C, Caballero FG and de Andrés CG. Dependence of martensite start temperature on fine austenite grain size. Scr. Mater. 2008;58:134-137.

[76] Yang HS and Bhadeshia HKDH. Austenite grain size and the martensite-start temperature. Scr. Mater. 2009;60:493-495.

[77] Ghosh G and Olson GB. Kinetics of F.C.C. $\rightarrow$ B.C.C. heterogeneous martensitic nucleation-I. The critical driving force for athermal nucleation. Acta Metall. Mater. 1994;42:3361-3370.

[78] Williams DB and Carter CB. 9.3.B Bright-Field and Dark-Field Imaging. Transm. Electron Microsc. Part 1 Basics. Second edi. Springer;

[79] Wang P, Lu S, Li D, Kang X and Li Y. Investigation of phase tranformation of low carbon martensitic stainless steel ZG06Cr13Ni4Mo in tempering process with low heating rate. Acta Metall. Sin. 2008;44:681-685.

[80] Villa M and Somers MAJ. Thermally activated martensite formation in ferrous alloys. Scr. Mater. 2018;142:46-49.

[81] LeBrun T, Nakamoto T, Horikawa K and Kobayashi H. Effect of retained austenite on subsequent thermal processing and resultant mechanical properties of selective laser melted 17-4 PH stainless steel. Mater. Des. 2015;81:44-53.

[82] Kromm A, Brauser S, Kannengiesser T and Rethmeier M. High-energy synchrotron diffraction study of a transformation induced plasticity steel during tensile deformation. J. Strain Anal. Eng. Des. 2011;46:581-591.

[83] Xiong XC, Chen B, Huang MX, Wang JF and Wang L. The effect of morphology on the stability of retained austenite in a quenched and partitioned steel. Scr. Mater. 2013;68:321-324.

[84] Brauser S, Kromm A, Kannengiesser T and Rethmeier M. In-situ synchrotron diffraction and digital image correlation technique for characterizations of retained austenite stability in low-alloyed transformation induced plasticity steel. Scr. Mater. 2010;63:1149-1152. 
[85] Yan K, Liss K-D, Timokhina IB and Pereloma E V. In situ synchrotron X-ray diffraction studies of the effect of microstructure on tensile behavior and retained austenite stability of thermo-mechanically processed transformation induced plasticity steel. Mater. Sci. Eng. A. 2016;662:185-197.

[86] Oliver EC, Daymond MR, Withers PJ and Mori T. Stress Induced Martensitic Transformation Studied by Neutron Diffraction. Mater. Sci. Forum. 2002;404407:489-494.

[87] Latypov MI, Shin S, Cooman BC De and Seop H. Micromechanical finite element analysis of strain partitioning in multiphase medium manganese TWIP + TRIP steel. Acta Mater. 2016;108:219-228.

[88] Liu H, Du L-X, Hu J, Wu H-Y, Gao X-H and Misra RDK. Interplay between reversed austenite and plastic deformation in a directly quenched and intercritically annealed 0.04C-5Mn low-Al steel. J. Alloys Compd. 2016;695:2072-2082.

[89] Anselmo N, May JE, Mariano NA, Nascente PAP and Kuri SE. Corrosion behavior of supermartensitic stainless steel in aerated and CO2-saturated synthetic seawater. Mater. Sci. Eng. A. 2006;428:73-79.

[90] Woollin P. Understanding and Avoiding Intergranular Stress Corrosion Cracking of Welded Supermartensitic Steel. NACE Corros. Conf. Expo (Corrosion 2007). 2007. p. 5379-5394.

[91] Solheim KG, Solberg JK, Walmsley J, Rosenqvist F and Bjørnå TH. The role of retained austenite in hydrogen embrittlement of supermartensitic stainless steel. Eng. Fail. Anal. 2013;34:140-149.

[92] Andersson JO, Helander T, Höglund L, Shi P and Sundman B. Thermo-Calc \& DICTRA, computational tools for materials science. Calphad Comput. Coupling Phase Diagrams Thermochem. 2002;26:273-312.

[93] Bojack A, Zhao L and Sietsma J. Thermodynamic Analysis of the Effect of Compositional Inhomogeneity on Phase Transformations in a $13 \mathrm{Cr} 6 \mathrm{Ni} 2 \mathrm{Mo}$ Supermartensitic Stainless Steel. Solid State Phenom. 2011;172-174:899-904.

[94] Borgenstam A, Engström A, Höglund L and Ågren J. DICTRA, a tool for simulation of diffusional transformations in alloys. J. Phase Equilibria. 
2000;21:269-280.

[95] Larsson H. A model for 1D multiphase moving phase boundary simulations under local equilibrium conditions. Calphad Comput. Coupling Phase Diagrams Thermochem. 2014;47:1-8.

[96] Morito S, Huang X, Furuhara T, Maki T and Hansen N. The morphology and crystallography of lath martensite in alloy steels. Acta Mater. 2006;54:53235331.

[97] Miyamoto G, Shibata A, Maki T and Furuhara T. Precise measurement of strain accommodation in austenite matrix surrounding martensite in ferrous alloys by electron backscatter diffraction analysis. Acta Mater. 2009;57:1120-1131.

[98] Stan M and Reardon BJ. A Bayesian approach to evaluating the uncertainty of thermodynamic data and phase diagrams. Calphad. 2003;27:319-323.

[99] Kattner UR. The thermodynamic modeling of multicomponent phase equilibria. Jom. 1997;49:14-19.

[100] Hillert M. Empirical methods of predicting and representing thermodynamic properties of ternary solution phases. Calphad. 1980;4:1-12.

[101] Kuehmann C, Tufts B and Trester P. Computational design for ultra highstrength alloy. Adv. Mater. Process. 2008;166:37-40.

[102] Perrut M. Thermodynamic modeling by the calphad method and its applications to innovative materials. AerospaceLab. 2015;1-11.

[103] Nilsson J-O. Super duplex stainless steels. Mater. Sci. Technol. 1992;8:685-700.

[104] Ye D, Li J, Jiang W, Su J and Zhao K. Effect of Cu addition on microstructure and mechanical properties of $15 \% \mathrm{Cr}$ super martensitic stainless steel. Mater. Des. 2012;41:16-22.

[105] Jiang W, Zhao K, Ye D, Li J, Li Z and Su J. Effect of Heat Treatment on Reversed Austenite in Cr15 Super Martensitic Stainless Steel. J. Iron Steel Res. Int. 2013;20:61-65.

[106] Miller MK, Kelly TF, Rajan K and Ringer SP. The future of atom probe tomography. Mater. Today. 2012;15:158-165.

[107] Williams DBB, Carter CB, Barry Carter C, Carter CB and Barry Carter C. 
Transmission Electron Microscopy. 2nd ed. Transm. Electron Microsc. Springer; 2009. 